\title{
宮崎県のスイートピー生産者における生産費，作業および省力形質に対する意識調査
}

\author{
中村 薰 $^{1 *} \cdot$ 福元孝一 ${ }^{1 a} \cdot$ 郡司定雄 $^{1} \cdot$ 明石 良 $^{2}$ \\ 1 宮崎県総合農業試験場８80-0212 宮崎市佐土原町下那珂 \\ 2 宮崎大学フロンティア科学実験総合センター 889-2192 宮崎市学園木花台西
}

\section{Survey on the Attitude of Sweetpea (Lathyrus odoratus L.) Growers in Miyazaki Prefecture towards Production Costs, Farming Operations, and Labor-saving Characteristics}

\author{
Kaoru Nakamura $^{1 *}$, Koichi Fukumoto ${ }^{1 a}$, Sadao Gunji ${ }^{1}$ and Ryo Akashi ${ }^{2}$ \\ ${ }^{1}$ Miyazaki Agricultural Research Institute, Sadowara Shimonaka, Miyazaki 880-0212 \\ ${ }^{2}$ Frontier Science Research Center, University of Miyazaki, Miyazaki 889-2192
}

\begin{abstract}
To determine the potential for the breeding of tendril-less sweetpea cut flower cultivars, an awareness survey was conducted among sweetpea farmers from the 97 sweetpea farms in Miyazaki Prefecture, Japan, in 2009. The sweetpea farmers included farm managers and their family members. The questions included in the survey pertained to the growing area used, factors responsible for the most significant production management costs, most laborious cultural practices, degree of necessity of tendrils, degree of eagerness to grow tendril-less cultivars, and desirable varietal characteristics. The survey showed that the average growing area for the 46 farm managers who answered this question in the survey was $17.3 \mathrm{a}$, and the growing area per laborer was $3.2 \mathrm{a}$. There was a significant positive correlation between the number of laborers and sweetpea-growing area $\left(\mathrm{r}=0.91^{* *}\right)$. The answers were divided according to 3 attributes pertaining to the farmers and examined. The attributes were: (1) the position of the participant, i.e., farm manager or family member; (2) the kind of labor used on the farm, i.e., family or employed labor; and (3) the size of the sweetpea-growing area. In reply to the question on the factors responsible for the most significant production management costs, the farm managers and family members selected employment costs, the family labor farmers selected the shipping costs, and the employed labor farmers selected the employment costs. The farmers who had a sweetpea growing area smaller than 10 a selected shipping as the most significant production management cost, whereas the farmers who had a sweetpea growing area larger than 10 a selected the employment costs. In response to the question on the most laborious cultural practices, "Yuin," i.e., training pertaining to removing the tendrils and lateral shoots, and "Tsurusage," i.e., training pertaining to resetting of the growing point from the top of the supporting net to a lower position in the supporting net, were selected, regardless of the attribute of each farmer. In response to the question on the degree of necessity of tendrils, "either" was selected, regardless of the attribute of each farmer. In response to the question on the degree of eagerness to grow tendril-less cultivars, the farm managers selected the option "add the tendril-less cultivar in candidate cultivars." This result showed that the farm managers expected that the absence of tendrils in these cultivars would be a labor-saving trait. In response to the question on desirable varietal characteristics, both farm managers and family members selected resistance to bud drop, a long vase life, high ratio of sales to production, and high yields more often than labor-saving traits, in spite of the response given to the question on the degree of eagerness to grow tendril-less cultivars.
\end{abstract}

Key Words : breeding objective, employment cost, tendril-less, training

キーワード：育種目標，雇用費，無巻きひげ，誘引

\author{
緒言 \\ スイートピー (Lathyrus odoratus L.) は, 我が国の重要な \\ 切り花品目のひとつである. つる性の一年生マメ科植物で \\ 2011 年 10 月 8 日 受付. 2012 年 3 月 22 日 受理. \\ 本報告の概要は平成 21 年度園芸学会九州支部第 49 回大会で発 \\ 表した。 \\ * Corresponding author. E-mail: nakamura-kaoru@pref.miyazaki.lg.jp \\ a 現在 : 宮崎県庁
}

あるスイートピーは，一対の小葉の先に巻きひげがある複 葉を持ち，その巻きひげを支持体に絡めることによって上 方へ伸長する.

しかしながらスイートピーの切り花営利栽培では，巻き ひげは不要な器官であり, 誘引作業の中で摘除される. 巻 きひげは誘引ネットや隣接株の茥葉打よび花梗に絡みつ き, 誘引作業を困難にし, 切り花品質をも低下させるため である，また，主枝 1 本仕立ての栽培であるため，葉腋か ら発生する腋芽もすべて摘除する。 スイートピー栽培では 
スイートピーの茎頂部が伸張し誘引ネットの上端に達する と，茎頂部を管理しやすい高さに誘引しな拈す「つる下げ」 といら作業がある。これらの「誘引」と「つる下げ」は多 大な労力を必要とし, 宮崎県に打訂る経営管理指標では, スイートピー 10 a 1 作当たりの労働時間 4,423 時間のうち 「誘引」は 1,056 時間，「つる下げ」は 420 時間となってい る（宮崎県農政水産部，2010a）。これは，宮崎県に抢ける 電照ギクの 3 月出荷作型の 10 a 1 作当たり労働時間の 627.5 時間, バラのロックウール栽培の 10 a 1 年間当たり労働時 間の 1,608 時間（宮崎県農政水産部，2010a）と比較して著 しく多い. スイートピーの切り花営利栽培では, この多大 な労働時間が課題となって抢り, 井上（2007）も「つる下 げ」や「巻きひげ切り」などの管理労力の低減の必要性を 指摘している.

ところで，スイートピーには，無巻きひげ形質の葉，す なわち巻きひげが数対の小葉に変化した, 巻きひげの無い 羽状複葉を持つ品種（以下，「無巻きひげ品種」とする）が あり，花田 (2003), Hanada・Hirai (2003), Nakamura ら （2010）は「無巻きひげ形質」は巻きひげを除去する必要が ないため，省力的形質であると報告している，そのため， この無巻きひげ形質が切り花品種に導入されれば, 生産者 は巻きひげを除去する作業から解放され，労働時間の大幅 な軽減が可能となる. 現在, 市販されている切り花用無巻 きひげ品種群に冬咲き性のセレモニーシリーズ 3 品種があ る（農山漁村文化協会, 2002）。しかし, 1980 年代に輸入 種子に打いて冬咲き性と春咲き性が混在し（林ら，1986; 井 上，1996）生産現場で問題となったため, 生産者は自家採 種によって必要な種子を確保している（林ら，1986）こと, 宮崎県で栽培されている品種は主に春咲き性であることか ら，宮崎県に抢いては，これらの市販切り花用無巻きひげ 品種の栽培は行われていない. 本調査は, スイートピーの 主産県である宮崎県に执いて省力化が期待できる品種とし て，無巻きひげ品種の育成を行うに当たり，その有望性に ついて検討するため, 97 戸の生産者を対象に生産規模や生 産費, 作業項目, 無巻きひげ形質, 無巻きひげ品種の栽培 および望ましい品種の形質についてアンケート調査を実施 したものである。

\section{材料および方法}

\section{1. アンケート調查の対象および手法}

アンケート調査は, 宮崎県内 8 地域のらち, 南那珂, 北 諸県, 巟湯, 東臼杵北部, 東臼杵南部および西臼杵の 6 地 域の JA スイートピー生産部会に所属する 97 戸のスイート ピー農家を対象に, 2009 年 $2 \sim 3$ 月に行った. アンケート は, 集出荷場などで用紙を配布し, 回答は直接またはファッ クスで回収した。回答は経営主ばかりでなく家族専従者に も求めた。な技，アンケート調査は無記名とした。

\section{2. アンケート調査の内容}

アンケート調査の内容は以下のと抢りとした.
1）性別，2）経営主か家族専従者か，3）スイートピ一経 営面積（単位：a）４）スイートピー経営に従事する家族專 従者和よび雇用者の人数, 5) スイートピー経営において最 も注意する生産費の項目:「種苗費」,「肥料費」,「農薬費」, 「諸材料（ネット・八サミなど）費」,「燃料費」,「雇用費」, 「出荷（出荷箱，手数料など）経費」「その他」からの択一 （以下，本文扮よび第 2 表に扎いて「諸材料（ネット・八サ ミなど）費」,「出荷（出荷箱，手数料など）経費」はそれ ぞれ「諸材料費」，「出荷経費」とする. )，6）スイートピー 経営に扔いて最も労力が必要と思われる作業項目:「種子冷

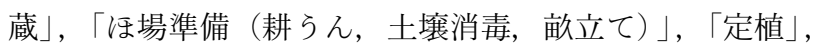
「水管理」,「誘引（巻きひげ・腋芽の除去, はさみあげ)」, 「つるゲ」,「農薬散布」,「収穫」,「出荷調整（収穫後出荷 場までの作業)」，「採種」からの択一（以下，本文拉よび第 3 表に沶いて「ほ場準備（耕ら几，土壌消毒，畧立て）」, 「誘引（巻きひげ・腋芽の除去，はさみあげ）」,「出荷調整 (収穫後出荷場までの作業)」はそれぞれ「淿場備」「誘 引」,「出荷調整」とする.），7）スイートピーの巻きひげは 必要か:「必要」,「どちらかといらと必要」,「どちらでもか まわない,「どちらかといらと不要」,「不要」からの択一, 8）無巻きひげ品種が, 現在作付けしている巻きひげ形質の 品種と遜色ない収量・品質であるとき，作付けしたいか： 「作付けしたい」,「導入する品種候補に入れる」,「わからな い」,「どちらかといらと導入したくない」，「作付けしたく ない」からの択一，9）無巻きひげ品種について意見: 自由 記述方式，10）品種に望ましいと考兄られる形質は何か： 「オリジナル花色」, 「高収量」,「高規格率」,「高品質（花持 ちが良いなど)」,「付加価值（香りが良い，化粧品の原料な ぞ)」,「省力」,「時期を通じて安定した収穫 (難落蕾)」,「珍 奇な形（超大輪やこれまでにない形）」「「その他」からの 3 項目の選択（以下，本文拈よび第 2 図に执いて「高品質（花 持ちが良いなど)」,「付加価值（香りが良い，化粧品の原料 など)」,「時期を通じて安定した収穫（難落蕾)」，「珍奇な 形（超大輪やこれまでにない形）」はそれぞれ「花持ち」， 「付加価值」,「難落蕾」, 「珍奇な形」とする. ), 11）試験場 への意見要望：自由記述，の計 11 項目である.

集計に当たり, 栽培面積扣よび従事者数等は経営主の データから集計を行った．5）扣よび6）の生産費と作業項 目について択一の回答を求めた設問に対し, 複数回答もし くは無回答であったものはその設問の集計から除いた，7) および 8）の巻きひげの必要性と無巻きひげ品種の作付け に対する設問に対し無回答は「どちらでもかまわない」る しくは「わからない」として集計し，複数の回答があった 回答はその設問の集計から除いた。 また，栽培面積の記述 が無い回答は10)の望ましい形質の集計にのみに採用した. 10）の 3 択の設問に 3 未満の回答があったものは不足する 回答数を「無回答」に分類した.

結果のらち, 最も注意する生産費, 最も労力が必要と思 わ和る作業，巻きひげの必要性および無巻きひげ品種の作 
付けに対する意識については, 回答者を経営主と家族専従 者の違い, 雇用の有無, 栽培面積の違いという 3 種類の属 性により分けて集計を行った.

\section{結 果}

\section{1. アンケート調査の配布および回収数}

アンケートは 97 戸の農家に配布し, 78 部回答を得た. 回 答者の性別は男性が 48 人で女性が 30 人であった。 また， 経営主の回答は 46 人で，そのらち男性が 41 人で女性が 5 人であった (第 1 表)。家族専従者の回答は 32 人で，その 万ち男性は 7 人で女性が 25 人であった.

\section{2. 経営主の栽培面積と従事者数}

回答には同一経営内の経営主と家族専従者が含まれてい る恐れがあるため, 経営主 46 人の回答から栽培面積および 栽培従事者数について集計した. 第 1 表に栽培面積 $10 \mathrm{a}$ ご との経営主数を示した. 経営主数は $10 \mathrm{a}$ 末満が 12 人で, $10 \mathrm{a}$ 以上 $20 \mathrm{a}$ 未満が 17 人, $20 \mathrm{a}$ 以上 $30 \mathrm{a}$ 未満が 10 人, $30 \mathrm{a}$ 以上 $40 \mathrm{a}$ 未満が 5 人, $40 \mathrm{a}$ 以上 $50 \mathrm{a}$ 未満が 1 人, $50 \mathrm{a}$ 以上 $60 \mathrm{a}$ 末満が 0 人, そして $60 \mathrm{a}$ 以上 $70 \mathrm{a}$ 未満が 1 人であっ

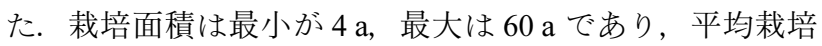
面積は $17.3 \mathrm{a}$ であった. 栽培面積が $40 \mathrm{a}$ 末満の経営は全体 の $95.7 \%$ 占めていた. 男性経営主の平均栽培面積は $18.7 \mathrm{a}$ であるのに対し，女性経営主は $5.8 \mathrm{a}$ と小さく, すべて $10 \mathrm{a}$ 未満であった.

第 1 表 経営主の性別による栽培面積別人数

\begin{tabular}{|c|c|c|c|c|c|c|c|c|c|}
\hline \multirow{2}{*}{ 性別 } & \multicolumn{7}{|c|}{ 栽培面積（a） } & \multirow[b]{2}{*}{ 合計 } & \multirow{2}{*}{$\begin{array}{c}\text { 平均 } \\
\text { 栽培面積 } \\
\text { (a) }\end{array}$} \\
\hline & $\sim 10$ & $\sim 20$ & $\sim 30$ & -4 & $\sim 5$ & $\sim 6$ & -70 & & \\
\hline 男性 & 7 & 17 & 10 & 5 & 1 & 0 & 1 & 41 & 18.7 \\
\hline 女性 & 5 & 0 & 0 & 0 & 0 & 0 & 0 & 5 & 5.8 \\
\hline 全体 & 12 & 17 & 10 & 5 & 1 & 0 & 1 & 46 & 17.3 \\
\hline
\end{tabular}

$\mathrm{z} \sim 10$ は $10 \mathrm{a}$ 末満を示す

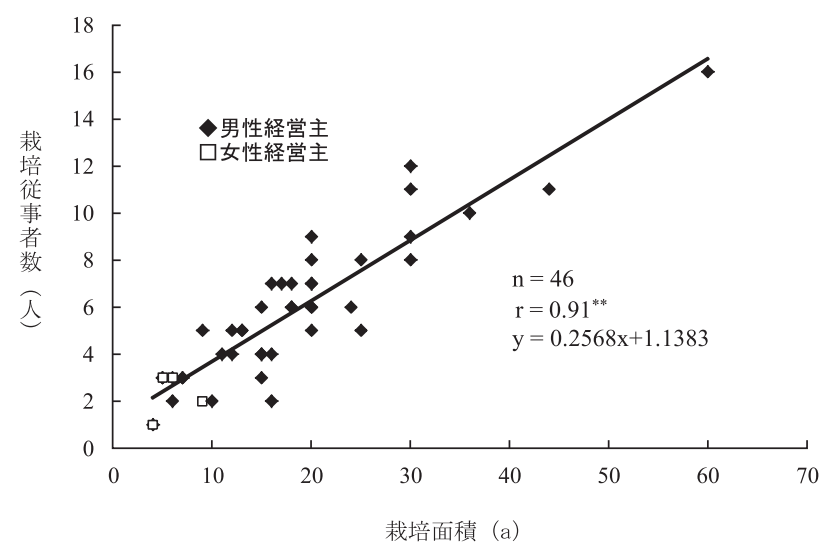

第 1 図 宮崎県のスイートピー経営主に打ける栽培面積と栽 培従事者数

平均栽培面積 : $17.3 \mathrm{a}$, 平均栽培従事者数 : 5.6 人 **1\%水準で有意な正の相関を示す

1 戸当たりの経営主打よび家族専従者を含む栽培従事者 数は, 最少が 1 人, 最多が 16 人であり，その平均は 5.6 人 であった．経営主を除く家族専従者数は，最少が 0 人，最 多が 4 人で，その平均は 1.7 人であった。 また，雇用者数 は，最少が 0 人，最多が 14 人で，その平均は 2.8 人であっ た. 農家に扔ける栽培従事者 1 人当たりの栽培面積は $3.2 \mathrm{a}$ であり，スイートピー栽培面積と栽培従事者数の関係は 1 $\%$ 水準で有意な正の相関 $\left(\mathrm{r}=0.91^{* *}\right)$ を示した（第 1 図）.

\section{3. 最も注意する生産費への意識}

最も注意する生産費への問いに対する有効回答数は55で あった (第 2 表)．経営主と家族専従者の違い, 雇用の有無 および栽培面積の違いによる最も注意する生産費への意識 の差を第 2 表に示した．経営主が最も注意する生産費は 31 人中「雇用費」が 16 人で最も多く，次いで「出荷経費」の 9 人であった．家族専従者では 24 人中「雇用費」が 11 人 で最も多く，次いで「出荷経費」と「然料費」がそれぞれ 5 人であり, 経営主と家族専従者の意識間に有意な差は認 められなかった。一方，雇用を有しない生産者は 12 人中

第 2 表 経営主と家族専従者，雇用の有無および栽培面積の違いによる最も注意する生産費への意識の違い

\begin{tabular}{|c|c|c|c|c|c|c|}
\hline 区分 & 燃料費 & 雇用費 & 出荷経費 & その他 ${ }^{2}$ & 合計 & 有意性 ${ }^{y}$ \\
\hline 経営主 & 5 & 16 & 9 & 1 & 31 & \multirow{2}{*}{ n.s. } \\
\hline 家族専従者 & 5 & 11 & 5 & 3 & 24 & \\
\hline 雇用なし & 4 & 0 & 6 & 2 & 12 & \multirow{2}{*}{$* *$} \\
\hline 雇用あり & 6 & 27 & 8 & 2 & 43 & \\
\hline \multicolumn{7}{|l|}{ 栽培面積（a） } \\
\hline $0 \sim 10^{\mathrm{x}}$ & 3 & 0 & 6 & 1 & 10 & \multirow{4}{*}{$* *$} \\
\hline $10 \sim 20$ & 4 & 10 & 6 & 3 & 23 & \\
\hline $20 \sim 30$ & 1 & 11 & 0 & 0 & 12 & \\
\hline $30 \sim$ & 2 & 6 & 2 & 0 & 10 & \\
\hline
\end{tabular}

z 種苗費, 肥料費, 農薬費, 諸材料費, その他の経費を含む

y フィッシャーの正確確率検定による, **：1\%水準で有意, n.s. : 有意差なし

${ }^{\mathrm{x}} 0 \mathrm{a}$ 以上 $10 \mathrm{a}$ 未満を示す 
「出荷経費」が 6 人で最も多く, 次いで「燃料費」が 4 人で あったのに対し, 雇用を有する生産者では 43 人中「雇用 費」が 27 人と最も多く, 次いで「出荷経費」の 8 人であ り, 雇用の有無によって生産者の意識間に $1 \%$ 水準で有意 な差が認められた。 また, 面積の違いでは $10 \mathrm{a}$ 未満の生産 者は 10 人中「出荷経費」が 6 人と最も多く, 次いで「燃料 費」が 3 人であったのに対し, $10 \mathrm{a}$ 以上 $20 \mathrm{a}$ 未満の生産者 は 23 人中「雇用費」が 10 人と最も多く, 次いで「出荷経 費」の 6 人であった. $20 \mathrm{a}$ 以上 $30 \mathrm{a}$ 未満抒よび $30 \mathrm{a}$ 以上の

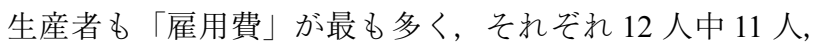
10 人中 6 人であった. このように栽培面積によって最も注 意する生産費への意識が異なり, $1 \%$ 水準で有意な差が認め られた。

\section{4. 最も労力が必要と思われる作業項目への意識}

最も労力が必要と思われる作業項目への意識に対する有 効回答数は 51 であった (第 3 表). 経営主と家族専従者の 違い, 雇用の有無拉よび栽培面積の違いによる最も労力が 必要と思わ机る作業項目への意識の差を第 3 表に示した. 経営主では 31 人中「つる下げ」が 13 人で最も多く, 次い で「誘引」の 11 人であったのに対し，家族専従者では 20
人中「誘引」が 10 人で最も多く，次いで「出荷調整」の 4 人であり，「つる下げ」は 3 番目の 3 人であった．経営主と 家族専従者の違いによって, 最も労力が必要と思われる作 業項目への意識に有意な差は認められなかった，雇用を有 しない生産者は 12 人中「つる下げ」が 7 人で最も多く, 次 いで「誘引」と「注場準備」がそれぞれ 2 人であったのに 対し, 雇用を有する生産者は 39 人中「誘引」が 19 人で最 も多く, 次いで「つる下げ」の 9 人であった。.しかしなが ら，雇用の有無により最も労力が必要と思われる作業項目 への意識に有意な差は認められなかった。 また，面積の違 いでは $10 \mathrm{a}$ 未満の生産者では 10 人中「つる下げ」が 4 人 と最も多く, 次いで「誘引」が 3 人であったのに対し, 10 a 以上 $20 \mathrm{a}$ 末満の生産者は 26 人中「誘引」と「つる下げ」が それ卆れ 10 人と最も多かった. $20 \mathrm{a}$ 以上 $30 \mathrm{a}$ 未満の生産 者は 9 人中「誘引」が 6 人で最も多く, 次いで「注場準備」 の 2 人であった. $30 \mathrm{a}$ 以上の生産者は 6 人中「誘引」と「出 荷調整」がそれぞれ 2 人で同数であった，栽培面積の違い に上る最も労力が必要と思わ机る作業項目への意識に有意 な差は認められなかった。

第 3 表 経営主と家族専従者, 雇用の有無および栽培面積の違いによる最も労力が必要と思われる作業項目への意識の違い

\begin{tabular}{|c|c|c|c|c|c|c|c|}
\hline 区分 & ほ場準備 & 誘引 & つる下げ & 出荷調整 & その他 ${ }^{z}$ & 合計 & 有意性 ${ }^{y}$ \\
\hline 経営主 & 3 & 11 & 13 & 3 & 1 & 31 & \multirow{2}{*}{ n.s. } \\
\hline 家族専従者 & 2 & 10 & 3 & 4 & 1 & 20 & \\
\hline 雇用なし & 2 & 2 & 7 & 1 & 0 & 12 & \multirow[b]{2}{*}{ n.s. } \\
\hline 雇用あり & 3 & 19 & 9 & 6 & 2 & 39 & \\
\hline \multicolumn{8}{|c|}{ 栽培面積（a） } \\
\hline $0 \sim 10^{\mathrm{x}}$ & 1 & 3 & 4 & 2 & 0 & 10 & \multirow{4}{*}{ n.s. } \\
\hline $10 \sim 20$ & 2 & 10 & 10 & 3 & 1 & 26 & \\
\hline $20 \sim 30$ & 2 & 6 & 1 & 0 & 0 & 9 & \\
\hline $30 \sim$ & 0 & 2 & 1 & 2 & 1 & 6 & \\
\hline
\end{tabular}

$\mathrm{z}$ 種子冷蔵, 定植, 水管理, 農薬散布, 収穫, 採種の作業を含む

y フィッシャーの正確確率検定による, n.s. : 1\%水準で有意差なし

${ }^{\mathrm{x}} 0 \mathrm{a}$ 以上 $10 \mathrm{a}$ 未満を示す

第 4 表 経営主と家族専従者，雇用の有無扣よび栽培面積の違いによる巻きひげの必要性への意識の違い

\begin{tabular}{|c|c|c|c|c|c|c|c|}
\hline 区分 & 必要 & $\begin{array}{l}\text { どちらかと } \\
\text { いらと必要 }\end{array}$ & $\begin{array}{l}\text { どちらでも } \\
\text { かまわない }\end{array}$ & $\begin{array}{l}\text { どちらかと } \\
\text { いらと不要 }\end{array}$ & 不要 & 合計 & 有意性 ${ }^{\mathrm{z}}$ \\
\hline 経営主 & 6 & 6 & 16 & 8 & 10 & 46 & \multirow{2}{*}{ n.s. } \\
\hline 家族専従者 & 4 & 8 & 13 & 3 & 2 & 30 & \\
\hline 雇用なし & 1 & 3 & 9 & 1 & 2 & 16 & \multirow[b]{2}{*}{ n.s. } \\
\hline 雇用あり & 9 & 11 & 20 & 10 & 10 & 60 & \\
\hline \multicolumn{8}{|l|}{ 栽培面積（a） } \\
\hline $0 \sim 10^{\mathrm{y}}$ & 0 & 2 & 8 & 4 & 3 & 17 & \multirow{4}{*}{ n.s. } \\
\hline $10 \sim 20$ & 4 & 8 & 12 & 3 & 5 & 32 & \\
\hline $20 \sim 30$ & 6 & 2 & 3 & 2 & 2 & 15 & \\
\hline $30 \sim$ & 0 & 2 & 6 & 2 & 2 & 12 & \\
\hline
\end{tabular}

zフィッシャーの正確確率検定による, n.s. : 1\%水準で有意差なし

${ }^{\mathrm{y}} 0 \mathrm{a}$ 以上 $10 \mathrm{a}$ 末満を示す 


\section{5. 巻きひげの必要性}

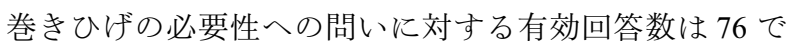
あった (第 4 表)。経営主と家族専従者の違い, 雇用の有無 および栽培面積の違いによる, 巻きひげの必要性への意識 の差を第 4 表に示した. 経営主 46 人中「どちらでもかまわ ない」が 16 人で最も多く, 次いで「不要」の 10 人であっ た．家族専従者も 30 人中「どちらでもかまわない」が 13 人で最も多く，次に「どちらかといらと必要」の 8 人であっ た．経営主と家族専従者によって巻きひげの必要性への意 識に有意な差は認められなかった。雇用を有しない生産者 では 16 人中「どちらでもかまわない」が 9 人で最も多く, 次いで「どちらかといらと必要」が 3 人であった，雇用を 有する生産者も 60 人中「どちらでもかまわない」が 20 人 で最も多く，次いで「ぞちらかといらと必要」の 11 人で あった，雇用の有無によっても巻きひげの必要性への意識 に有意な差は認められなかった，栽培面積の違いでは $10 \mathrm{a}$ 未満の生産者は 17 人中「どちらでもかまわない」が 8 人と 最も多く, 次いで「どちらかといらと不要」が 4 人であっ た. $10 \mathrm{a}$ 以上 $20 \mathrm{a}$ 未満の生産者は 32 人中「どちらでもか まわない」が 12 人と最も多く, 次いで「どちらかというと 必要」が 8 人であった. $20 \mathrm{a}$ 以上 $30 \mathrm{a}$ 未満の生産者は 15 人 中「必要」が 6 人で最も多く, 次いで「どちらでもかまわ ない」の 3 人であった. $30 \mathrm{a}$ 以上の生産者は 12 人中「どち らでもかまわない」が 6 人で最も多く,「不要」,「どちらか というと不要」,「ぞちらかといらと必要」がそれぞれ 2 人 で,「必要」は 0 人であった. 栽培面積の違いよる巻きひげ の必要性への意識に有意な差は認められなかった。

\section{6. 無巻きひげ品種の作付けに対する意識}

無巻きひげ品種の作付けに対する意識への有効回答数は 77 であった (第 5 表). 経営主と家族専従者の違い, 雇用 の有無および栽培面積の違いによる無巻きひげ品種の作付 けに対する意識の差を第 5 表に示した。経営主は 46 人中 「導入する品種候補に入れる」が 22 人で最も多く, 次いで 「作付けしたい」の 8 人であった．家族専従者では 31 人中
「かからない」が 16 人で最も多く, 次いで「導入する品種 候補に入れる」の 7 人であった. 経営主と家族専従者によっ て無巻きひげ品種の作付梳対する意識には $1 \%$ 水準で有 意な差が認められた。雇用を有しない生産者では 16 人中 「わからない」と「導入する品種候補に入れる」がそれぞれ 6 人で最も多かった．雇用を有する生産者は 61 人中「導入 する品種候補に入れる」が 23 人で最も多く, 次いで「わか らない」の 17 人であった. 雇用の有無によって無巻きひげ 品種の作付けに対する意識に有意差は認められなかった. また, 栽培面積の違いでは $10 \mathrm{a}$ 未満の生産者は 17 人中「わ からない」が 6 人と最も多く, 次いで「導入する品種候補 に入れる」が 5 人であった. $10 \mathrm{a}$ 以上 $20 \mathrm{a}$ 末満の生産者は 32 人中「導入する品種候補に入れる」が 12 人と最も多く, 次いで「わからない」が 10 人であった. $20 \mathrm{a}$ 以上 $30 \mathrm{a}$ 末 満の生産者は 15 人中「導入する品種候補に入れる」が 7 人 で最も多く，次いで「わからない」の3人であった， $30 \mathrm{a}$ 以上の生産者は 13 人中「導入する品種候補に入れる」が 5 人で最も多く，次いで「わからない」の 4 人であった，栽 培面積の違いによって無巻きひげ品種の作付けに対する意 識に有意な差は認められなかった.

\section{7. 無巻きひげ品種についての自由記述意見}

無巻きひげ品種について自由記述意見として18件の回答 が得られた. そのらち 10 件が無巻きひげ品種の栽培に対し 不安を訴光るものであった. 10 件の内容をまとめると「小 葉が多いため他の株が日照不足になる，栽植密度が低くな る」が 4 件, 「誘引作業が遅孔た場合につるが倒れる」が 4 件, 「草勢が強く過繁茂する」が 2 件であった，一方，「作 業遅れが不安だが省力になる」,「作付けしたい」といった 作付けに意欲を示した意見が 4 件であった，他に「誘引の 回数が増えるので省力にならないのでは」と省力効果を疑 ら意見が 2 件,「無巻きひげ形質を知らない」が 1 件であっ た。「無巻きひげ形質を知らない」は家族専従者からの回答 であったままた，「無巻きひげ品種を栽培しており，作業が 早いが落蕾しやすいので小面積にしている」という記述が

第 5 表 経営主と家族専従者, 雇用の有無拉よび栽培面積の違いによる無巻きひげ品種の作付けへの意識の違い

\begin{tabular}{|c|c|c|c|c|c|c|c|}
\hline 区分 & 作付けしたい & $\begin{array}{l}\text { 導入する品種 } \\
\text { 候補に入れる }\end{array}$ & わからない & $\begin{array}{l}\text { どちらかといらと } \\
\text { 導入したくない }\end{array}$ & 作付けしたくない & 合計 & 有意性 ${ }^{z}$ \\
\hline \multirow{2}{*}{$\begin{array}{l}\text { 経営主 } \\
\text { 家族専従者 }\end{array}$} & 8 & 22 & 7 & 7 & 2 & 46 & \multirow{2}{*}{$* *$} \\
\hline & 2 & 7 & 16 & 4 & 2 & 31 & \\
\hline \multirow{2}{*}{$\begin{array}{l}\text { 雇用なし } \\
\text { 雇用あり }\end{array}$} & 0 & 6 & 6 & 4 & 0 & 16 & \multirow[b]{2}{*}{ n.s. } \\
\hline & 10 & 23 & 17 & 7 & 4 & 61 & \\
\hline \multicolumn{7}{|l|}{ 栽培面積（a） } & \multirow{5}{*}{ n.s. } \\
\hline $0 \sim 10^{\mathrm{y}}$ & 2 & 5 & 6 & 4 & 0 & 17 & \\
\hline $10 \sim 20$ & 6 & 12 & 10 & 2 & 2 & 32 & \\
\hline $20 \sim 30$ & 1 & 7 & 3 & 2 & 2 & 15 & \\
\hline $30 \sim$ & 1 & 5 & 4 & 3 & 0 & 13 & \\
\hline
\end{tabular}

zフィッシャーの正確確率検定による, **: 1\%水準で有意, n.s. : 有意差なし

${ }^{\mathrm{y}} 0 \mathrm{a}$ 以上 $10 \mathrm{a}$ 末満を示す 


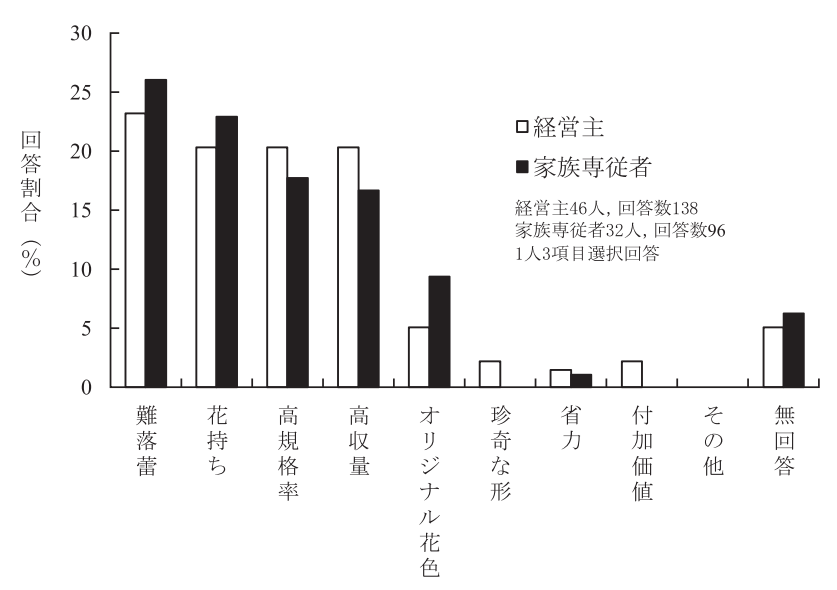

第 2 図経営主および家族専従者が望ましいと考光る品種の 形質の割合

無回答は 1 人 3 項目中選択されなかった回答数

1 件あった. これらの意見を作付けに対する意識で「不安」, 「前向き」,「どちらでもない」の 3 項目に分け，他の意識へ の回答と同じく経営主と家族専従者の違い, 雇用の有無, 栽培面積の違いといら 3 つの属性で検定を行ったが, 作付 けに対する意識と 3 つ属性の間に関連は認められなかっ た (データ略).

\section{8. 望ましいと考える品種の形質}

望ましいと考光る品種の形質についての回答結果を第 2 図に示した. 経営主, 家族専従者とも「難落蕾」,「花持ち」, 「高規格率」,「高収量」の 4 項目が他の項目よりも多く, こ れらの回答割合はそれぞれ $16.7 \%$ 以上であった。一方，「才 リジナル花色」や「珍奇な形」,「省力」, 「付加価值」の回 答は $10 \%$ 以下で割合が低かった.

\section{9. 試験場への要望}

試験場に対しては「落蕾しない品種」や「高温に強い品 種」の育成に対する要望が記述されていた.

\section{考察}

本報告は, スイートピーの主産県である宮崎県に拈いて, 切り花用の無巻きひげ品種の育成を行らに当たり, その有 望性について検討するため，2009 年に 97 戸の生産者を対 象に生産規模や生産費, 作業項目, 無巻きひげ形質, 無巻 きひげ品種拈よび望ましい品種の形質についてアンケート 調査を実施し，その結果をとりまとめたものである．調査 対象の生産者が属するJA スイートピー生産部会は宮崎県 内の注全域にわたって組織されている宮崎県内最大のス イートピーの生産者組織である. 同年の宮崎県内のスイー トピー農家戸数は 131 戸（宮崎県農政水産部, 2010b）であ り，本調査は宮崎県に打けるスイートピー生産者の意識を 十分反映するものと考えられた，スイートピーにおいて， このよらな大規模な意識調査事例は知る限りなく, 生産者 意識を知るらえで貴重な資料と考えられる.

経営主の平均栽培面積は $17.3 \mathrm{a} て ゙ ~ 40 \mathrm{a}$ 未満の経営が全体
の 95.7\%を占めていた（第 1 表）。また，経営主を除く平均 家族専従者数は 1.7 人であった. スイートピー栽培面積と 栽培従事者数の関係は有意な正の相関を示している（第 1 図）ことから，栽培面積が大きくなるに従って栽培従事者 は増加することを示している，これらから，宮崎県の多く のスイートピー生産者は $40 \mathrm{a}$ までの栽培規模内で, 夫婦を 中心とした家族労働に栽培面積に応じて雇用労働を加える ことで労働力を確保していると考えられた.

スイートピーは，農作物の中で集約的とされる花き（塚 本，1985）の中で最も労働集約型の品目とされており（井 上，2007），宮崎県に打ける経営管理指標では，スイート ピー 10 a 1 作当たり労働時間は 4,423 時間となっており, 他 品目と比較して著しく多い（宮崎県農政水産部，2010a）. そのため, 栽培従事者 1 人当たり栽培面積は, 経営主の栽 培規模を決定する際に重要な制限要因となる. 井上 (1982) は 1980 年に神奈川県で栽培事例を調査し, 栽培従事者 1 人 当たりの適正な栽培面積は， $1.74 \sim 2.64$ a としている. 当 時のつる下げ誘引方法は，つるを輪状に巻き下げ，縦糸に 誘引する「巻き下げ」であり, 現在以上に多くの労力を要 していた．現在は佐賀県で考案されたつるを横に倒して ネットに誘引する作業性の良い「横倒し（ずらし）」が多く の産地で採用された（井上，1996）ことから, 後に井上 （2007）は適正栽培面積を 3 a としている. 宮崎県では, 1983 年に栽培が始まった当初から「横倒し（ずらし）」を採用し ており，現在もすべての生産者が「横倒し（ずらし）」で栽 培を行っている. 宮崎県の農業改良普及員は生産者の経営 事例から栽培従事者 1 人当たりの適正な栽培面積は 3.33 $4.95 \mathrm{a}$ (八反田，1989），3.33 a（井上，1997）とそれぞれの 時期に記述している. 今回の調査結果では栽培従事者 1 人

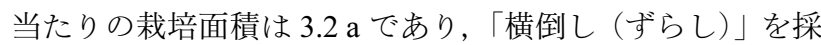
用したこれらの記述とほぼ一致するものであった。 これら のことから，つる下げ方法により適正栽培面積は異なり， 「横倒し (ずらし)」方法では $3.2 \mathrm{a}$ 前後が栽培従事者 1 人当 りの適正栽培面積と考えられた.

宮崎県が作成したスイートピーの経営指針では, $20 \mathrm{a} の$ ほ場に建設できるビニルハウス面積である $17.64 \mathrm{a}$ を標準栽 培規模としている（宮崎県農政水産部，2010a）。今回の調 査では経営主の平均栽培面積は $17.3 \mathrm{a}$ であり (第 1 表), 経 営指針の規模に近い数值となった．栽培規模について国内 の他主産県の栽培指針等で比較すると, 神奈川県は $1,320 \mathrm{~m}^{2}$ (半田, 2002), 兵庫県は $1,000 \mathrm{~m}^{2}$ （兵庫県農林水産部普及 教育課，2002）となっている，また，経営費に含まれる費目 では, 宮崎県は雇用費を含めている（宮崎県農政水産部, 2010a）が，神奈川県と兵庫県は家族労働を基本に考えてお り，経営費に雇用費は含まれていない（半田，2002；兵庫 県農林水産部普及教育課，2002）。このように，スイート ピー生産者の栽培規模は神奈川県や兵庫県では家族労働中 心の規模であるのに対して，宮崎県では家族労働力に雇用 労働力を加えた大規模の経営であると考えられる. 
今回の調査結果では, 経営主の性別により平均栽培面積 が異なり, 男性経営主は 18.7 a であるのに対し, 女性経営 主は 5.8 a と小さかった. 一般に男性経営主の場合は配偶者 および家族と栽培を行っている事例が匡とんぞであるが， 女性経営主に抢いては, 配偶者が別の職業に就いている事 例を筆者らは把握している. 女性経営主の面積が小さい原 因は，このように家族労働力が少ないことによるものと推 察された。

最も注意する生産費では, 経営主と家族専従者とも「雇 用費」が最も多く，農家内の立場にかかわらず「雇用費」 が最も注意する生産費であることが明らかになった（第 2 表), 雇用を有しない生産者は「出荷経費」が最も多く, 次 いで「燃料費」であるのに対し，雇用を有する生産者は「雇 用費」が最も多く, 雇用の有無によって生産費に対する意 識が大きく異なることが明らかになった，雇用を有しない 生産者の意識は, 宮崎県よりも生産規模の小さい神奈川県 や兵庫県で行われた調查結果（井上, 1982; 半田, 2002) や 経営指標（兵庫県農林水産部普及教育課, 2002）に打ける 生産費の高い順と一致した，雇用を有する経営では「雇用 費」,「出荷経費」, 「燃料費」の順で意識が強く, 宮崎県の 経営指標（宮崎県農政水産部，2010a）飞抢ける生産費の高 い順と一致した。 また, 経営主と家族専従者に拄いて, 「雇 用費」を選択した回答者はすべて雇用を有する回答者であ ることが第 2 表から読反取れる.ささらに栽培面積の違いで は, 栽培面積が $10 \mathrm{a}$ 未満の生産者は雇用を有しない生産者 と似た傾向であり, $10 \mathrm{a}$ 以上の 3 水準の栽培面積の生産者 は雇用を有する生産者と似た傾向を示していた。 これらの ことから, 宮崎県はスイートピー主産県の中では生産規模 が大きい県であり, 経営主, 家族専従者とも最も注意する 生産費は「雇用費」であるが, 雇用の有無や栽培面積によっ てその意識は異なり, 雇用を有しない, もしくは面積が $10 \mathrm{a}$ 未満の生産者は生産規模の小さい神奈川県や兵庫県の生産 者と同じ意識を有していると考兄られた。

最も労力が必要と思われる作業項目では, 経営主と家族 専従者, 雇用の有無扎よび栽培面積の多少によって有意な 意識の差は認められず,「誘引」と「つる下げ」の 2 つの作 業が最も労力が必要と思われる作業項目として認識されて いることが明らかになり（第 3 表），「誘引」，「つる下げ」 の労働時間の削減は大きな課題と考兄られた.

巻きひげの必要性についての意識でも, 経営主と家族専 従者, 雇用の有無掞よび栽培面積の多少にかかわらずそれ ぞれの意識に有意な差は認められず, 生産者全体では「ど ちらでもかまわない」が最も多かった（第 4 表）。「必要」 および「どちらかというと必要」を選択した生産者は, 自 由記述回答にも記載されていたように繁忙期に誘引作業が 遅れてしまった場合, 巻きひげがないと植物体が自らを誘 引ネットに固定できずに倒れてしまらことを恐れるためと 推察され，「不要」拈よび「どちらかといらと不要」と回答 した生産者は比較的作業の遅れが生じない生産者と考兄ら
れた。「どちらでもかまわない」と回答した生産者は，巻き ひげの存在を何らかの理由で作業遅れが発生した場合の 「保険」として意識しているのではないかと考光られる。ま た，無巻きひげ品種の栽培が無く認知度が低いことも「ど ちらでもかまわない」が多かった理由と考光られた。

無巻きひげ品種の作付けに対する意識に抢いて，経営主 は 46 人中「作付けしたい」が 8 人，「導入する品種候補に 入れる」が 22 人であり，作付けに対し積極的な回答が多 かった (第 5 表). 宮崎県では, 栽培される品種は自家採種 でまかなわれて扣り, 新たな品種の導入は生産者間の種子 の譲渡もしくは交換によって行われている，スイートピー はその生育が栽培環境に大きく左右される品目であること から, 生産者は導入元生産者の栽培状沉を十分観察し, 情 報を收集して慎重に品種の選択を行なっている. そのため, このように積極的な回答が多いことは, 経営主は無巻きひ げ品種の持つ省力効果に期待しているものと考兄られる. 一方，家族専従者に「わからない」の回答が多く，経営主 と家族専従者の間には有意な意識の差が認められた，家族 専従者に「わからない」といら回答が多かった理由は, 品 種の選択は経営主の判断で行われやすいことや,「無巻きひ げ形質を知らない」といら自由記述回答があることから， 家族専従者は経営主に比べ研修会などへの参加機会が少な く，生産に関する情報量が少ないためではないかと考兄ら れた，雇用の有無や栽培面積の多少による無巻きひげ品種 の作付けに対する意識に有意差は認められなかった.

無巻きひげ品種についての自由記述意見からは「誘引作 業が遅れた場合につるが倒れる」,「小葉が多いため他の株 が日照不足になる，栽植密度が低くなる」，「草勢が強く過 繁茂する」といら不安を持つ生産者の存在が明らかになっ た.これらから，無巻きひげ形質の葉が，小葉が多いため 葉面積が大きい, 草勢が強いと生産者は感じていると思わ れる，これまで，無巻きひげ品種の葉面積については調査 されていない，今後，無巻きひげ品種の育成と併せて，葉 の形態調査を行い，営利栽培を行うらえで効率的な形態に ついて検討を行ら必要があると考兄られた。 また，突然変 異個体からの選抜と考兄られる無巻きひげ品種を栽培して いる生産者から，その省力性を感じている旨の貴重な回答 が得られた。この生産者は無巻きひげ品種の作付けへの設 問には「作付けしたい」と回答して抢り，充分に省力性に 魅力を感じていることがうかがえた.

望ましい品種と考学る品種の形質（第2図）では，経営 主および家族専従者とも「省力」よりも「難落蕾」，「花持 ち」，「高規格率」および「高収量」といった形質を望んで いることが明らかになった. 2009 年度に宮崎県内 JA が取 り扱ったスイートピーの品種や染色を含む 283 アイテムの らち, 品種の出荷量上位 10 位は‘ファーストレディー’, ‘ステラ’, ‘ロイヤルチェリー’, ‘エンゼルキッス’, ‘ロー ズピンク’, ‘ロイヤルホワイト’, ‘ネオグレース’, ‘グレー ス’，“美々’执よび‘ハッピー’であり，全出荷量の約 $40 \%$ 
を占めている（宮崎県経済連スイートピー出荷データ内部 資料)。これらの品種はいずれも高収量で, 規格率も高い品 種であり,「高規格率」,「高収量」形質が多くの生産者に支 持されていることが理解される. また，スイートピーは是 天で落蕾しやすく, 気温が上昇する時期は花持ち日数が低 下しやすい（井上，2007）ため, 「難落蕾」,「花持ち」はス イートピーに扔いて重要な課題である。 スイートピー生産 者は, 落蕾の軽減と充分な花持ちを確保するため天候の変 動に敏感に反応して栽培管理を行っているが, 特に連続し た曇天による落蕾はほぼ毎年発生するため, 市場への安定 供給掞よび生産者の収益確保への極めて大きな障害となっ ている，これらを克服する品種はまだ育成されておらず， これらの形質は今後の重要な育種目標であるといえる。一 方,「省力」については, 営利栽培に適した切り花用の無巻 きひげ品種は現状では導入されていないため, その省力効 果が一般に認識されていないことや, 生産者にとってスイー トピー栽培に充分な労力が必要であることは栽培の前提条 件であることから，生産者の認識は低いと考兄られた，これ らのことから, 経営主打よび家族専従者とも無巻きひげ形質 の省力効果による生産コスト低減への期待よりも, 「難落蕾」 や「花持ち」,「高規格率」拈よび「高収量」の形質を持つ品 種による粗收益の向上への期待が上回ったと考兄られた.

このように経営主や家族専従者は「雇用費」や「誘引」 作業を意識し，無巻きひげ品種の導入に意欲を示している 一方で, 粗収益の向上を目指していることが明らかになっ た. しかしながら, 花き流通統計（農林水産省大臣官房統 計部, 2004, 2010) によると近年の花き市場に打けるスイー トピーの 1 本当たりの卸売単価は低迷している. 1998 年の 卸売数量は 137,751 千本で 1 本当たりの卸売価格が 34 円で あるのに対し, 2008 年は卸売数量が 123,857 千本と減少し ているにもかかわらず 1 本当たりの卸売価格は 27 円と 10 年間で卸売単価が $21.6 \%$ 減少して沏り, 高単価はかつてほ ど期待できない状況となっている. 宮崎県に抏ける経営指 標に扔いても2001年 (宮崎県南那珂農業改良普及センター, 2001）と2010 年（宮崎県農政水産部，2010a）を比較する と, 指標の規模 $17.64 \mathrm{a}$ 当たり粗収益は 14,412 千円から 13,611 千円に減少しているのに対し, 雇用費は 2,803 千円 から 3,247 千円に，八ウス等燃料費は 180 千円から 440 千 円に, 出荷経費は 3,879 千円から 3,900 千円とそれぞれ増加 している. 井上（1996，2007）も単価の低下を指摘してお り, 今後のスイートピーの経営では低コスト・安定生産を 図ることが重要であるとしている.

果菜類に扔いては, 単価の低迷や担い手不足, 担い手の 高齢化により省力化育種が既に取り組まれており, 成果を 挙げている（齊藤ら， 2005; 平井ら，2004）。 スイートピー に执いても単価の低下や生産費の増加ばかりでなく果菜類 同様に担い手不足, 担い手の高齢化の課題への対応は避け られないものであり, 経費の削減による収益の確保を目的 とした省力形質の育種は重要な課題と考兄られる.
以上のことから，今後のスイートピーの経営安定のため には, 低コスト・安定生産が図れる形質を持つ品種の育成 が必要と考光られ，「省力」による低コスト化が期待される 無巻きひげ品種の育成は「難落蕾」や「花持ち」などの形 質を持つ品種の育成同様に重要と考兄られた.

\section{摘 要}

省力的形質とされる無巻きひげ形質を持つスイートピー 切り花品種の育成の有望性を検討するため, 生産者に対し 2009 年にアンケート調查を実施した. 調査対象は宮崎県の 97 戸の経営主と家族専従者とし, 設問は生産規模, 最も注 意する生産費, 最も労力を必要とすると思わ和る作業項目, 巻きひげの必要性，無巻きひげ品種の作付けに対する意向 および望ましい品種の形質とした. 回答が得られた 46 人の 経営主の平均栽培面積は $17.3 \mathrm{a}$ であった。栽培従事者 1 人 当たりの栽培面積は $3.2 \mathrm{a}$ であり, 栽培面積と栽培従事者数 の関係は有意な正の相関を示した $(r=0.91 * *) .78$ 人の回 答者を経営主か家族専従者か, 雇用の有無, 栽培面積の大 きさといら 3 つカテゴリーで分けて集計を行った，最も 注意する生産費では, 経営主と家族専従者の意識に差は無 く,「雇用費」が最も多く選択されたが，雇用を有しない生 産者および栽培面積が $10 \mathrm{a}$ 未満の生産者では「出荷経費」 が最も多く選択され，雇用を有する生産者拉よび $10 \mathrm{a}$ 以上 の面積の生産者では「雇用費」であった．最も労力が必要 と思われる作業項目は「誘引」と「つる下げ」が，巻きひ ゲの必要性では「どちらでもかまわない」が回答者の属性 にかかわらず最も多く選択された，無巻きひげ品種の作付 けに対する意識では, 経営主では「導入する品種候補に入 れる」が最も多く選択され, 経営主が省力効果に期待して いることが明らかになった．望ましいと考光る品種の形質 では経営主，家族専従者とも「難落蕾」，「花持ち」，「高規 格率」打よび「高収量」が「省力」よりも多く選択された。

謝 辞 本調査を実施するに当たり，宮崎県内の花き担 当普及指導員扣よび各 JA の花き担当職員には多大なるご 協力をいただいた．宮崎県内のスイートピー生産者には快 く回答くださった．また，神奈川県農業技術センタ一の栁 下良美氏，兵庫県立農林水産技術総合センターの山中正仁 博士，宮崎県経済農業協同組合連合会の加藤麻紀氏には資 料の提供等ご協力賜った. ここに深く感謝します.

\section{引用文献}

花田裕美. 2003. スイートピーにおけるDNA多型による分 類法とDNA マーカーによる巻きひげ性選抜法の開発. 和歌山農総技七特研報. 6: 1-92.

Hanada, H. and M. Hirai. 2003. Development of a genetic marker linked to the tendril trait of Sweet pea (Lathyrus odoratus L.). Breeding Sci. 53: 7-13.

半田 貴. 2002. スイートピー栽培の経済性標準指標の策 定. 神奈川農総研平成 13 年度試験研究成績書（経営情 
報）．11-14.

八反田憲生. 1989. スイートピー栽培の新技術. 農業と生 活. 24(1): 56-57. 宮崎県農林技術連絡協議会. 宮崎.

林 勇・大川 清 - 山元恭介. 1986. スイートピーの生 育, 開花習性に関する研究（第 1 報）生態型の異なる スイートピーの生育・開花習性. 神奈川園試研報. 33: 36-44.

平井 剛・杉山 裕・中野雅章. 2004. 短節間カボチャ‘つ るなしやっこ’の収量性および省力性. 園学研. 3:287290.

兵庫県農林水産部普及教育課. 2002. 地域農業経営ハンド ブック. 7: 376-377.

井上伸之. 1997. スイートピーの産地化に向けて。農業と 生活. 31(6): 20-21. 宮崎県農林技術連絡協議会. 宮崎. 井上知昭. 1982. 湘南のスイートピー (増補版). p. 193-205. 湘南温室組合. 神奈川県寒川町.

井上知昭. 1996. スイートピー。農及園. 71: 195-200.

井上知昭. 2007. スイートピーをつくりこなす. p. 20-28. 農文協. 東京.

宮崎県南那珂農業改良普及センタ一．2001．宮崎県農業経 営管理指針 (南那珂地域版). 宮崎県南那珂農業改良普
及センター。宮崎.

宮崎県農政水産部．2010a. 宮崎県農業経営管理指針．宮崎 県. 宮崎.

宮崎県農政水産部. 2010b. 宮崎の花. 宮崎県. 宮崎.

Nakamura, K., K. Fukumoto and R. Akashi. 2010. Genetic variability of morphological and cultural characteristics in sweetpea (Lathyrus odoratus L.). J. Japan. Soc. Hort. Sci. 79: 179-191.

農林水産省大臣官房統計部. 2004. 全国の品目別卸売数量・ 価額・価格の推移. 平成 14 年花き流通統計調査報告. 22-29. （財）農林統計協会. 東京.

農林水産省大臣官房統計部. 2010. 全国の品目別卸売数量, 卸売価額及び卸売価格. 平成 20 年花き流通統計調査報 告. 24-27. 農林水産省大臣官房統計部. 東京.

農山漁村文化協会．2002．花卉品種名鑑．275-278．農文 協. 東京.

齊藤猛雄・吉田建実・森下昌三．2005．育種面から見た省 力・快適化への研究戦略. 野菜茶業研究集報. 2: 29-36. 塚本洋太郎. 1985. 花卉園芸の特徵と生産状況. p. 17-33. 花开総論. 養賢堂. 東京. 